\title{
VINEGAR TOM: A PLAY ABOUT WITCHES WITH NO WITCHES IN IT
}

Svjetlana Ognjenović, University of East Sarajevo, svjetjung@yahoo.ca

Original scientific paper

DOI: 10.31902/fll.33.2020.3

UDC: 821.111.09-2

\begin{abstract}
Although it focuses on the $17^{\text {th }}$ century witch hunt, the play Vinegar Tom actually dramatises historical degradation of women and their ultimate demonization in the form of witches. Challenging the official version of the story of 'witches', Caryl Churchill reveals the truth about them as "old, poor, single, or sexually unconventional" women (Churchill, 1985). Following her lead, our intention was to reveal and elaborate on how female sexuality, transgressive imagination and healing skills became a threat to the Church and its dogma, and how this triple threat actually represents a set of three most common accusations against the witches. Furthermore, in the style of new historicist literary approach, we will try to relate this horrendous attack on women with the rise of capitalism and Protestantism, two repressive ideologies that not only legitimized this misogynist campaign but planned it and organized it on the state level. What makes this play significant even today is its contemporariness which is underlined, among other things, by the direct address to audience and the use of modern dresses on stage. Thus, our concluding point would be that every historical period has its own "witches" be it entire races, groups or individual dissidents.
\end{abstract}

Keywords: witches, women, witch hunts, patriarchy, sexuality, victims.

"Hysteria is a woman's weakness. Hysteron, Greek, the womb. Excessive blood causes an imbalance in humours. The noxious gasses that form inwardly every month rise to the brain and cause behaviour contrary to the patient's real feelings. After bleeding you must be purged. Tonight you shall be blistered. You will soon be well enough to

be married."

(Churchill, Vinegar Tom, 1985)

\section{Introduction}

Caryl Churchill's Vinegar Tom is "a play on witches with no witches in it" (Churchill, Introduction, 1985) which is why it is at most adequate to name the play after a black cat who never makes an actual appearance. Although it focuses on the $17^{\text {th }}$ century witch hunt, the play actually dramatises historical degradation of women and their ultimate demonization in the form of witches. The choice of such a 
theme was obviously influenced by feminist orientation of the author, as well as entire theatre company Monstrous Regiment that took part in creating this dramatic work, but also by the literature they all read during the workshop period. Two most significant books were studies Witches, Midwives and Nurses: A History of Women Healers (1973) on the origin of exclusively male professional medicinal practice and Witchcraft in Tudor and Stuart England (1970) on detailed reports from Essex witch trials. Caryl Churchill writes:

One of the things that struck me reading the detailed accounts of [these] witch trials [.... [ w was how petty and everyday the witches' offences were, and how different the atmosphere of actual English witchhunts seemed to be from my received idea, based on slight knowledge of the European witchhunts and films and fiction, of burnings, hysteria and sexual orgies. I wanted to write a play about witches with no witches in it; a play not about evil, hysteria and possession by the devil, but about poverty, humiliation and prejudice, and how the women accused of witchcraft saw themselves. (1985, 130)

Challenging the official version about the witches, as devilish servants and demons from hell sent to the earth to tempt and torture fearful believers, Churchill reveals that the women accused of witchcraft were often "those on the edge of society, old, poor, single, or sexually unconventional" (Introduction). She unfolds that "witches" were actually scapegoats during the turbulent era when it was necessary to distract the masses from the real causes of their plight and channel their grievances into violent and angry outbursts against another innocent social group. This is what one of the key songs from the play is about:

Burn your troubles away.

Sometimes it's witches, or what will you choose?

Sometimes it's lunatics, shut them away.

It's blacks and it's women and often it's Jews.

We'd all be quite happy if they'd go away.

Find something to burn.

Let it go up in smoke.

Burn your troubles away. (154)

"Witches" in Vinegar Tom are four women who fit the mentioned criminal categories either by their social status or their alleged mistakes: Alice is sexually uninhibited young woman, Joan is a poor old woman, Ellen is a healer and Susan indoctrinated housewife who, in the moment of weakness, performs an abortion thus breaking the 
patriarchal taboo on the sanctity of family. The only one that manages to avoid death by hanging is a sixteen-year-old Betty, a landowner's daughter, who pays for the rebellious attempt to gain her independence by enforced marriage to the chosen, allegedly suitable, husband. The rest of the women from the play belong to the patriarchal or new capitalist ideology: Margery, who accuses Joan of being a witch, because she wants to get hold of her meadow and annex it to her ever expanding land estate, and Goody, who is an assistant to a well known witch hunter, because she actually makes profit on each of the alleged demonic crimes. Goody's servility towards the system is two-fold: she supports its capitalist matrix because her main goal is profit and its patriarchal matrix because she does not have a choice at all: "Better [hunting witches] than staying home a widow. I'd end up like old women you see, soft in the head and full of spite with their muttering and spells" (ibid., 168).

\section{Womanhood and witchcraft}

By conventional patriarchal standards, the role of a woman is bound strictly to the household and a man; she is either a wife or is about to become one. Women who do not belong to these narrowly defined categories are sometimes labelled and excommunicated as "whores". This highly problematic notion is touched upon by Churchill in the very first scene of the play when an unnamed man in black, that sexually uninhibited Alice has a fling with, scoffs at her: "what name would you put to yourself? You're not a wife or a widow. You're not a virgin. Tell me a name for what you are" (137). By asking her one specific question: "What name would you give yourself?", this Man, who functions as a spokesman for the entire male gender and as a supporter of the patriarchal system, contemptuously rejects Alice as "a whore", that is as a symbol of his own sin. Nevertheless, despite her reputation due to which "she will never find a husband", as the conventional and frightened Susan bleakly prognoses, Alice is not a prostitute. She is a single mother, who wishes to take care of herself, her old mother and her son, all by herself; she wants to satisfy her sexual desire but does not want to get married; she desires a man, not a husband. Her rebellion against the society is basically about her striving to become a subject, and not an object of sin, and, as is the case with the rest of the characters from the play, Alice has to be punished for striving to be an independent woman. As noted by Victoria Sullivan, every independent activity of these village women becomes an appropriate excuse for the charges of witchcraft: "If they want a man, it must be the devil's urging; if they attempt to heal with 
herbs, they are soliciting Satan; if they gripe, and beg, and complain, they are revealing a witch's temperament" (Sullivan 1997, 185). Their independence has to be punished because it challenges the status quo and disrupts the existing power relations.

Alice's promiscuity can even be questioned considering her conversation with Susan about the Man from the beginning of the play. In this conversation Caryl Churchill alludes to Alice's fixation on this particular man. From the subtext it can be seen that he is a married, rich man who, as such, can never be hers: Alice is poor and belongs to a wrong class. From this point of view, one can rightfully question whether the female promiscuity is sinful as a rule or it becomes sinful only when it transgresses social barriers? With this question, Caryl Churchill problematizes the issue of double morality and hypocrisy that go hand in hand with socially acceptable behaviour. While men are allowed to have sexual affairs outside marriage, married women are punished twice: either they are confined into the domestic spheres without any opportunity to find happiness outside marriage or, if they do try to pursue this unattainable dream, they become adulteresses and lose everything they have - from reputation to family. Single women are even worse off since they have to find the proper balance in their affairs with men and juggle between their being too frigid or too "easy". Also, in the case of women involved with married men, it is customary to absolve the unfaithful husbands as frail victims of sexually insatiable and uncontrollable women who are, more often than not, socially stigmatised as prostitutes. Eva Figes (1986) in her study on patriarchal attitudes considers the prostitution as miniature version of "puritan" Victorian family structure, a kind of "sexual sewer for the wealthy" whose members took advantage of the unenviable economic situation of the poor working-class and basically forced them into prostitution while, at the same time, managed to preserve the fabricated image of "unchallenged purity of countless happy homes" (Figes 1986, 84). While the enforced sexual taboos of the past (still valid!) prescribed saintly image and behaviour for "proper" women nurturing in them frigidity and quite common neuroses, their husbands customarily found their own sexual pleasures among the "sinners" from the working class, who in most cases had to sell their bodies in order to survive ${ }^{1}$. Therefore, Victorian marriage, as E. Figes concludes,

\footnotetext{
${ }^{1}$ In English literature, an ideal womanhood was summed up and made popular by Coventry Patmore's narrative poem The Angel in the House that defines woman as utterly passive and submissive creature. Here are some of the lines from the poem: "A rupture of submission lifts / Her life into celestial rest; / There's nothing left of what
} 
was actually a kind of legalized prostitution (1986, 87). Enchanted circle, or better said, the iron cage that women persistently try (and, fortunately, increasingly manage) to find their way out of, is a dungeon for sexually active Alice, a poor single mother. The man she desires refuses her as a reject and simultaneously secures her the adequate reputation of "a girl from a ditch" who is, in the end of the play, sentenced to death exactly by those whose sexual advances she instantly refused.

When the other married man from the play, Jack, loses his sexual potency, it is exactly Alice whom he accuses of witchcraft, her crime being his impotence:

JACK: Witch... give it me back. You know. You took it from me these three months. I've not been a man since. You bewitched me. You took it off me. (...) Please, sweet good Alice, give it back... Give it me.

[He grabs her round the neck.]

(...)

[Alice puts her hand between his thighs.]

ALICE: There. It's back.

JACK: it is. It is back. Thank you, Alice. I wasn't sure you were a witch till then. (163-164)

A fear of female body has always been present in patriarchal societies where greedy sexual appetite was identified with woman embodied in the character of succubus who sexually molests men. Sexual potency in women or their natural nymphomania was also the reason why Sigmund Freud in his study Civilization and Its Discontents (1930) branded women as enemies of the civilization because they are allegedly unable to control their sexual instinct. It is highly ironic, as Eva Figes observes $(1986,49)$, that men should now complain about female sexual manipulation after they were the ones who did everything in their power to confine women to bedroom.

she was; / Back to the babe the woman dies, / And all the wisdom that she has/ Is to love him for being wise." However, Patmore himself - and therefore the Victorian ideal of womanhood in general - was influenced by Jean-Jacques Rousseau's most significant work Emile, or On Education (1762). In his controversial work, French philosopher (commonly famous for his more advanced motto of the French revolution "liberté, égalité, fraternité") puts forward surprisingly patriarchal pedagogical attitudes: „To be pleasing in his sight, to win his respect and love, to train him in childhood, to tend him in manhood, to counsel and console, to make his life pleasant and happy, these are the duties of woman for all time, and this is what she should be taught while she is young." See: Eva Figes, Patriarchal Attitudes: Women in Society, Persea Books New York, 1986, p. 105-107. 
In the patriarchal society, whose main idea is conflict and rivalry, the only imaginable alternative to male domination is female domination. From this perspective, Eva Figes (1986) analyses the fear among men from sexually potent women as fear of their retribution and therefore a witch-hunt as embodiment of the same fear from castration expressed in a rather direct way. Together with Christian teachings that demonized women and separated spiritual and physical love by celebrating celibacy, it is no wonder that repressed sexuality caused twisted visions and sexually hypertrophied female witches in patriarchal societies. Here is an excerpt from the book Patriarchal Attitudes that sums up and explains our own views very illustratively and precisely:

Man is reason, woman is unreason, man is more spiritual, whether in intellect or moral goodness, than woman, who is more physical, animal and sensual. Therefore man has to control woman. And it all springs from the mistaken hope that man, rational man, can control the animal side of his own nature. But this is precisely what man can never do: the two aspects have to be reconciled, not set to war with each other. The more a man tries to control his lusts, the more powerful they become. It is an obvious phenomenon associated with repression: Adam refrained from satisfying his sexual appetite, and demons multiplied in the night. A small itch becomes devilish torment, what Augustine called, 'hell's black river of lust'. Woman, the object of that lust, made to take the blame for the dark, uncontrollable side of man's nature, takes demonic form and becomes a witch. (Figes, 1986, 57-58)

Witches are regularly identified as beings with animal sexual nature: therefore the common picture of perverted orgies, nudities, debauchery, and copulation with the devil. It can be said that witch hunt is actually the last desperate attempt of the Church to destroy the devil inside men - the devil that, ironically, the Church itself had placed there (Figes, 1986, 62). From a self-conscious, modern woman's perspective, aware of her sexuality and with "the pill" in her pocket, we can agree with Eva Figes's claim that "the desperate attempt of the Church" - to destroy the devil inside men - was finally frustrated either by the devil or the woman herself. The fates of so many emancipated women prove the point. On the other hand, that is from the perspective of approximately million innocent killed women, burned for their fabricated witchcraft, the success of the triumvirate patriarchal, Christian and capitalist ideologies - is undisputable. So, the impasse of the women from the play, and the leitmotif of the entire play, is dramatized both in the impossibility of an independent 
unconventional living and the futility of a struggle against the patriarchal conformism. This is why, in the very end, when an already modest utopian space seems to be closing even more, a desperate Alice admits:

I'm not a witch. But I wish I was. If I could live I'd be a witch now after what they've done. I'd make wax men and melt them on a slow fire. I'd kill their animals and blast their crops and make such storms, l'd wreck their ships all over the world. (...) Oh if I could meet with the devil now I'd give him anything if he'd give me power. There's no way for us except by the devil. If I only did have magic, I'd make them feel it (175).

In other words, "witches" become witches only when they are stripped of every possible chance to shape their own lives according to their own choice. Revenge, as a playwright Edward Bond says, indeed represents the pathology of justice.

Another witch of the play Vinegar Tom is Susan who functions as a foil to Alice's character. Not only that Susan is a willing mother and a wife, she is so utterly immersed in patriarchal ideology that she represents a true paradigm of an ideal woman of the times. She is obedient, submissive, frail, weak, frightened and always available for her marital duties in the bedroom. She is also a Fichtean woman that abandons her entire personality to her lover in order to lose herself in him: "Her own dignity requires that she should give herself up entirely as she is, and lives to her choice and should utterly lose herself in him. The least consequence is, that she should renounce to him all her property and all her rights. Henceforth she has life and activity only under his eyes and in his business. She has ceased to lead the life of an individual; her life has become a part of the life of her lover" (cited in Figes 1986, 126). Only just in her early twenties, Susan already has three children, three miscarriages, and in the very moment of her appearance in the play, she is pregnant again. Apart from not having any control over her body, Susan also shows how her brain is poisoned by the dominant ideology and its coercive dogmas she wholeheartedly trumpets. To Alice's proposal to end her pregnancy, Susan parrots:

They do say the pain is what's sent to a woman for her sins. I complained last time after churching, and he said I must think on Eve who brought the sin into the world that got me pregnant. I must think on how woman tempts man, and how she pays God with her pain having the baby. So if we try to get round the pain, we're going against God. (146)

Only when physical pain and exhaustion basically compel Susan to abort the child, she finally goes to a "cunning woman" Ellen. However, 
the guilt she feels about this is insufferable: "I'm sorry. I'm wicked." (162) Just like Jack who blames Alice for his problems with impotence, so infantile Susan blames Alice for her sin accusing her of being a witch that made her kill her unborn baby. A crucial moment that announces the triumph of the witch hunts as a mode of social control is Susan's betrayal that condemns Alice to death by hanging. As a critic Sian Adiseshiah notices, "the positive dramatisation of solidarity is replaced [here] with fear, division, and disunity, and the result is ritualised executions" (Adisesiah, 2009, 128). Disturbing efficiency of the dominant pedagogy is painfully evident in Susan's last monologue upon the gallows:

SUSAN: I was a witch and never knew it. I killed my babies. I never meant it. I didn't know I was so wicked. I didn't know I had that mark on me. I'm so wicked. Alice, let's pray to God we won't be damned. If we're hanged, we're saved, Alice, so we mustn't be frightened. It's done to help us. Oh God, I know now I'm loathsome and a sinner and Mr Packer has shown me how bad I am and I repent I never knew that but now I know and please forgive me and don't make me go to hell and be burnt forever -

ALICE: I'm not a witch.

SUSAN: Alice, you know you are. God, don't hear her say that (174175).

One might say that Vinegar Tom is a conspicuously feminist play, but the social class criticism, which is articulated in the play, is equally important as its critique of misogyny. Social submissiveness plays an important role, especially in the case of an old Joan, a poor widow, who does not have a man to take care of her, to cultivate the land for her or earn a living. Rejected, unprotected and useless, Joan is a social burden and a nuisance for her more well off neighbours, Margery and Jack: “I don't know why she's let stay. If we all lived like her it wouldn't be the fine estate it is." (139) Indeed, as Adiseshiah reminds us in her work:

it seems that population growth and changes in land-ownership created a group of poorer villagers whose ties to their slightly wealthier neighbours became more tenuous. People increasingly had to decide whether to invest their wealth in maintaining the old at a decent standard of living or in improvements which would keep them abreast of their yeoman neighbours. (2009, 121-122)

Capitalist drive surfaces when these two egoistical upstarts wish to get a hold of Joan's "meadow" and so enhance their property and their income. From their own selfish reasons (justified by capitalist 
expansion and the policy "everyone to himself"), Jack and Margery go to such an extent that they even accuse Joan of witchcraft: this is one of the ways Churchill uses to reveal the relationship between impersonal socio-historical conditions (e.g. individualist ideology) and personal human motivation.

What gives Margery a necessary context and an excuse for accusation is "the yeast scene". In this scene, Joan humbly begs her neighbour for some yeast "to make a small loaf of bread":

JOAN: A little small crumb of yeast and God will bless you for kindness to your poor old neighbour.

MARGERY: You're not so badly off, Joan Noakes. You're not on the parish.

JOAN: If I was I'd be fed. I should be on relief, then I'd not trouble you. There's some on relief, better off than me. I get nothing.

MARGERY: [...] I've no yeast. [...] Dirty old woman you are, smelling of drink, come in here day after day begging, and stealing, too, I shouldn't wonder...

JOAN: You shouldn't say that. (144)

When Joan finally tells her that she will be punished for her selfishness (helping poor people was one of the characteristics of the feudal system) and then, traditionally, curses her and the butter she makes, Margery ascribes all of the undoing on her estate to this "curse". In the same scene, Churchill also underlines the theme of criminalization of the poor, previously problematised in her play Light Shining in Buckinghamshire (1976), through the character of a beggar woman, Margaret Brotherton, who gets arrested and punished only for being a beggar.

Caryl Churchill gives political and economic importance to personal experience of another female character in the piece - a witch hunter called Goody. Being against women and on the side of their male opponents, Goody also reflects the lack of female solidarity. However, Churchill uses the opportunity to emphasize that Goody is in the same socially hopeless situation: in order to eat, she has to work, and since the only available job is witch finding, she reminds us how limited choices were in this particular situation by saying: "Better than staying home a widow." (168) Therefore, it becomes clear that apart from being an accomplice in crime, Goody is also a victim of the brutal society Churchill depicts in her play.

Betty, a young landowner's daughter, is not accused of witchcraft, but is equally important character in the play. Her covert rebellion against the destiny of a girl from her social class, which amounts to 
unconditional acceptance of marriage prearranged by her parents from purely economic reasons, enlists her among potential transgressors. Ordeal she is about to go through due to her rebellion does not include execution per se, but represents a kind of soul murder that was perfected by (male) medical doctors, pedagogues, psychiatrists, or state apparatus officials (Churchill wrote about this same topic in her previous plays Lovesick (1969), Schreber's nervous illness (1972) and Hospital at the time of the revolution (1972)). Initiation of such "beneficial" procedures is best given in the scene in which we can see Betty tied to a chair and Doctor who is about to "let blood", since this is the most efficient medicine for, as he claims, typically female, hysterical outbursts:

BETTY: Why am I tied? Tied to be bled. Why am I bled? Because I was screaming. Why was I screaming? Because I'm bad. Why was I bad? Because I was happy. Why was I happy? Because I ran out by myself and got away from them - Why was I screaming? Because I'm bad. Why am I bad? Because I'm tied. Why am I tied? Because I was happy. Why was I happy? Because I was screaming. (149)

According to Sian Adiseshiah, this scene contributes to the impact of impenetrable discourse that dominates and controls the women in the village and the "quasi-Socratic mode of questioning and answering displays, ironically, the full corruption and perversion of the deployment of logic" $(2009,124)$. At the first sight, one might say that Betty, being a rich landowner's daughter, has nothing in common with the depicted poor female lot, but using her example, Caryl Churchill shows that middleclass woman is only in somewhat better position than the women from lower classes. Betty's wealth saves her from death by hanging: "Doctor says he'll save me. He says I'm not a witch, he says I'm ill. He says I'm his patient so I can't be a witch. He says he's making me better." (169) However, despite the fact that rich girls "cannot" be witches, they have to overpower their "devilish" female nature and the best way to do so is the discipline of the patriarchal marriage. This is how even Betty - the girl who expressed her utopian desire for freedom by climbing a tree, first in order to see "the other side of the river" and then, by jumping off the tree and flying to that imagined place across the river (ibid., 140) - ultimately becomes "a thing she dreads most - a good wife" (Fitzsimmons, 1989, 33). Ellen, the healing woman, tries to persuade her that this is actually the only safe solution:

ELLEN: [...] Your best chance of being left alone is marry a rich man, because it's part of his honour to have a wife who does nothing. He has 
his big house and rose garden and trout stream, he just needs a fine lady to make it complete and you can be that. You can sing and sit on the lawn and change your dresses and order the dinner. That's the best you can do. What would you rather? Marry a poor man and work all day? Or go on as you're going, go on strange? That's not safe. (169)

Ellen, who persuades Betty to save herself by marriage, is the one critically and socially aware of the circumstances and restrictive possibilities for women. This is also the reason for her pro-pessimistic outlook at things: "I could ask to be swum. They think the water won't keep a witch in, for Christ's baptism sake, so if a woman floats she's a witch. And if she sinks they have to let her go. I could sink. Any fool can sink. It's how to sink without drowning." (169) Ellen tries to but cannot find a way out of the female impasse which is furthermore underscored with the modern song "If you float":

If you float you're a witch.

If you scream you're a witch

If you sink, then you're dead anyway.

If you cure you're a witch

Or impure you're a witch

Whatever you do, you must pay. (170)

Ellen is a paradigm of a female healer that Barbara Ehreinreich and Deidre English describe in their work Witches, midwives and nurses: A History of Women Healers first published in 1973. She functions as an alternative and a foil to the character of the Doctor: while he evokes Greeks and mythology to help him in healing, Ellen relies on proven healing techniques, her long experience and knowledge of herbs. The Doctor, by administrating ideological goals of the system, forces his female patients into malignant conformity, whereas Ellen offers them choice. Her cottage, as Sian Adiseshiah (2005) suggests writing on utopian possibilities in the play, serves as an unconventional space, a kind of woman utopia, a counter site and a relief from patriarchal domination.

Barbara Ehrenreich and Deirdre English (1973) offer detailed interpretation and an alternative version of the witch hunt which lasted for almost three hundred years (from the 14th to 17th centuries). By reminding their readers that close to one million people were killed during this craze ( $85 \%$ of them being women), these female authors justifiably refer to the witch hunt as "terror against female population" (Ehreinreich et al. 1973, 11). Most virulent attack coincides with the rise of capitalism and Protestantism, two repressive ideologies 
that not only legitimized this misogynist campaign but planned it and organized it on the state level. With joint effort, the state and the church performed this massacre and then falsified it in their histories as "mass hysteria" of women accused for witchcraft. Witch craze did not start "suddenly" among the country folk, Ehreinreich and English claim; it was not a kind of lynching ritual, nor an attempt of mass suicide - those were "well-organized campaigns, initiated, financed and executed by Church and State" (ibid., 9).

What the Church considered as a threat to its dogma was female sexuality, transgressive imagination and healing skills - this triple threat also represents a set of three most common accusations against witches. Misogyny in the Catholic and Protestant Church alike can be summed up in one sentence from the book Malleus Maleficarum, also known as, The Hammer of the Witches dating from 1484, that says: "What else is a woman but the enemy of friendship, an inescapable punishment, a necessary evil, a natural temptation, a desirable disaster, a danger in the home, a delightful detriment, an evil of nature, painted with nice color? (...) When a woman thinks alone, she thinks evil thoughts" (Mackay, 2009, 162-163). Not only that the Church proclaimed women as evil creatures, but it also stripped women of their maternity role by proclaiming the man as the maker of homunculus, or "little person", and woman as mere temporary incubator (Ehreinreich et al. 1973, 10-11). This is how the Church actually reformulated the old version of usurpation of motherhood previously referred to by Aeschylus in his Oresteia, on the very threshold of patriarchy ${ }^{2}$; finally it was also the Church that introduced the absurd fantasy about the post-apocalyptic era when all people will allegedly be reborn but in male bodies (ibid.). Therefore, witches posed a triple threat to the Church: they were women, healers and latent utopists. Especially despised were "good" witches or healers who used

\footnotetext{
${ }^{2}$ In this famous Greek classic, Orestes is acquitted for killing his mother on the grounds that he has not shed any kindred blood, and that a mother is a mere temporary vessel for the seed planted by a father - the one true parent. To confirm his claim - that birth excludes a mother figure - Apollo reminds the audience that the goddess Athens, according to the Greek myth, came into this world, not from the motherly womb, but her father's head. The trial ends with Athens's testimony in which she supports a father and speaks against a mother: "I am always for the male with all my heart, and strongly on my father's side." As R. Eisler concludes, referring to the same tragedy in her study The Chalice and the Blade, that Athens's betrayal of the feminine designates the end of the Goddess' Golden Age and her egalitarian harmonious community, and the beginning of the patriarchal era, in which, together with the matricide and subsequent acquittal, a man was "exonerated" of all feminine virtues as well: love, justice, compassion, care, empathy. Compare R. Eisler, The Chalice and the Blade, 78-81.
} 
to help people with their medical problems and whose healing practice Ehreinreich and English regard as "science of the time":

The witch-healer's methods were as great a threat (to the Catholic Church, if not the Protestant) as her results, for the witch was an empiricist: She relied on her senses rather than on faith or doctrine, she believed in trial and error, cause and effect. Her attitude was not religiously passive, but actively inquiring. She trusted her ability to find ways to deal with disease, pregnancy and childbirth - whether through medications or charms. In short, her magic was the science of her time. (ibid)

Due to its tendency to make ignorant people dependant on its dogma and alleged religious spirituality, the Church readily sided with the "professional" doctors, denouncing non-professional healing as equivalent to heresy: "'If a woman dare to cure without having studied she is a witch and must die' (of course, there wasn't any way for a woman to study)" (Ehreinreich et al. 1973, 17). Contrary to official medicine histories that see women as preordained to be nurses, but never doctors (because they are allegedly defeated by their own anatomy, and also by the power of the "superior" medical technology of the male professionals ${ }^{3}$ ), one should emphasize the following: "That the suppression of women health workers and the rise to dominance of male professionals was not a 'natural' process, resulting automatically from changes in medical science, nor was it the result of women's failure to take on healing work. It was an active takeover by male professionals" (ibid., 4). Ehrenreich and English point out that securing monopoly over the medical science was a part of the political struggle, which was more broadly a part of the historical struggle between sexes and classes, under the protection and patronage of the ruling class. "To know history", insist these two authors, "is to begin to see how to take up the struggle again" (ibid., 5). This insight can further be confirmed by Nancy Chodorow's claims (1979) that medicinal practice from the 19th century, together with the Church and patriarchal family, actually defined bourgeois woman as asexual and humble by nature. Doctors explained away every deviation from the norm and every female attempt to assert her personality from the medical point of view and then, on husband's suggestion or their own,

\footnotetext{
${ }^{3}$ Superiority in this context is ironical, because while female healers used authentic medicinal techniques, as well as proper knowledge on human anatomy, bones and herbs, the male professionals treated people with leeches, bleeding, chants, and other quasi-religious rituals.
} 
even performed the surgical removal of female reproductive organs that, according to their opinion, made women overtly sexual and thus independent (Chodorow, 1979, 93).

\section{Conclusion}

Our longer digression on the study Witches, midwives, and nurses is justified by the very quality of its content but also by the fact that this study served as a primary source for the play Vinegar Tom, as mentioned at the beginning of our analysis. Just like the authors of the study, who dwell on the historical background of the witch hunt, Caryl Churchill uses the same insights in her play. Thus, Churchill sums up already described misogyny in the Church in the last scene of her play that can almost serve as a monologue on women. Here, Churchill introduces another alienation effect, apart from songs, in the characters of Kramer and Sprenger, the authors of the notorious book on witches Malleus Maleficarum:

SPRENGER: Why is a greater number of witches found in the fragile feminine sex than in men?

KRAMER: 'All wickedness is but little to the wickedness of a woman.' Ecclesiastes.

SPRENGER: Here are three reasons, first because

KRAMER: woman is more credulous and since the aim of the devil is to corrupt faith he attacks them. Second because

SPRENGER: women are more impressionable. Third because

KRAMER: women have slippery tongues and cannot conceal from other women what by their evil art they know.

SPRENGER: Women are feebler in both body and mind so it's not surprising.

(...)

She is more carnal than a man ... A defect of intelligence... A defect of inordinate passions... Women have weak memories... She's a liar by nature... vain... more bitter than death... contaminating to touch... (Churchill, 1985, 177)

This kind of teaching about women was used as justification for witch hunts and thus supports Ehrenreich's claim that this hunt was indeed a legitimate organized state campaign against innocent women in England. However, in order to disrupt identification with the victims of Kramer's and Sprenger's doctrine and thus give way to potential defeatism among the public, Churchill downplays their misogynist philosophy by creating a contrast between their looks and their message. The actress that played Susan in the original setting of the 
play, Gillian Hanna says, "We didn't want to allow the audience to ever get completely immersed in the stories of the women in the play. We wanted to make them continually aware of our presence, of our relationship to the material, which was combative, anguished" (as quoted in Roberts, 2009, 186). For this reason, Churchill assigns the roles of Kramer and Sprenger to women and, on top of that, in order to enhance the comical effect even more, she dresses them in tail-coats and black gents hats, that used to be worn in shallow but commercially very popular musicals from the end of the 19th century. By showing the history in Brechtian manner, Churchill very effectively points to historical continuum of "the woman question", but also the possibility to answer this type of oppression more adequately than in the given period from the play. Therefore, the alienation device functions as the potential stimulus to find efficient political solutions to the posed problems.

This strategy is more than justified or else the ending of the play Vinegar Tom could easily be interpreted as a message of defeat and hopelessness (since the play ends with the deaths of four women and the entrapment of the survivors in the suffocating conformity of patriarchal marriage). What Geraldine Cousin refers to as "revolutionary possibilities" and Adiseshiah Sian as "utopian spheres" are eliminated within the play: instead of a real utopia, we are confronted with a pro-fascist false utopia that uses women as scapegoats, as was the case with the Jews in Nazi Germany, and the only other possibility is a negative marital utopia that provides a rather dubious sanctuary, and only to bourgeois women. However, by referring to contemporary versions of witch hunts in the last song of her play, Churchill insists on the idea that full awareness is a precondition to every utopian thought. This awareness, according to some feminist critics' opinions, should partly provide critical insight and contribute to contemporary debates on sexual politics and body politics, particularly significant during the seventies in the context of Women's Liberation Movement (WLM). Thus, Elaine Aston asserts that Joan represents "an aging body", Alice "a sexually active body", Susan "a birthing body" and Betty "a hysteric body" $(1997,28)$ - these bodies represent different versions of femininity and a deep apprehension of the patriarchal culture, so that one of the tasks for the audience today would also be to recognize and identify new subversive potentialities of the contemporary body. Perhaps more significant is Churchill's dramatisation of betrayal among women and tragic outcomes of the class antagonism - all of these contribute to the tragic ending of the play - which reflect the subsequent disruption within WLM during the 
eighties. The play reveals how absence of solidarity among various feminist groups (but also all oppressed races and classes) stands as insurmountable barrier to their final liberation even today. In this regard, the song ending the play Vinegar Tom - that takes form of a sequence of questions - points toward utopia not as an existing or imagined space, but as a process of constant and urgent questioning of historical mistakes without which the reality might look altogether different ${ }^{4}$ :

Look in the mirror tonight.

Would they have hanged you then?

Ask how they're stopping you know.

Where have the witches gone?

Who are the witches now?

Ask how they're stopping you now.

Here we are. (Churchill, 1985, 176)

This ending brings to mind another ending: the one from Brecht's play The Good Person of Szechwan (1942) when the heroine fails to be simultaneously a good person and also the one able to provide for herself and her child. Her failure to balance her own urge for survival and compassion towards others gives rise to a series of questions that audience has to find the answers to. They, of course, allude to the need and a nature of changes within the current system, the one where a person can "survive" only by abandoning her own humanity:

In your opinion, then, what's to be done?

Change human nature or - the world? Well: which?

Believe in bigger, better gods or - none?

How can we mortals be both good and rich?

The right way out of the calamity

You must find for yourselves. Ponder, my friends,

How man with man may live in amity

And good men - and women also- reach good ends.

There must, there must, be some end that would fit.

Ladies and gentlemen help us look for it! (Brecht, 1943, 106)

\footnotetext{
${ }^{4}$ See Miguel Abensour, The Persistent Utopija u L. Petrović, "Utopijski momenti u dramama M. Držića i M. Ravenhila", Interkulturni horizonti: južnoslovenske/evropske paradigme i srpska književnost, Kragujevac: Filum, 2009, 45-58. The main idea of the text we owe to our previously noted comment about Churchill's play, relies on Horkheimer's and Adorno's dialectical critique of enlightenment, and the thesis that the failure of revolutionary utopian idea does not mean that the idea should be rejected entirely, but only revised in order to find where and when the mistakes were made so that these can be avoided and corrected in the future.
} 
The questions that Brecht poses in his song are not, of course, exclusively the questions about the position of women, as is ultimately the case with the questions from the final song in Vinegar Tom. Not only the question "Who are the witches now", but entire play, can associate us to other, more recent, "democratic" witch hunts, such as McCarthy's persecution of the followers of the communist idea in the USA during the forties and fifties of the last century (when thousands of innocent men and women were accused of and charged for sedition and treason, and the Rosenbergs even executed), as well as other current affliction of the demonized nations, minorities or individual dissidents ${ }^{5}$. The victims of "witch hunt" in recent histories, especially in XX and XXI century, are not necessarily women, but womanhood principles and values that are in the patriarchal history mythically associated with feminine maternal nature. The fact that former US Secretary of State Madeleine Albright stated that a half of million children casualties, who died during the American aggression on Iraq, was a price worth paying for democracy $\left(\right.$ sic $\left.^{6}{ }^{6}\right)$, without flinching and without causing the official disapproval of any kind, clearly speaks about the kind of society we live in: it is the society in which the main obstacle to social hierarchy and acknowledgment is not gender identity any more, but inability or refusal (of men, women, nations) to give over to the archaic values of love, justice and empathy. Obviously, the origin of this refusal, as shown in the analysis of the play, lies in the conjunction of patriarchal and capitalist ideologies which secure their existence mainly through oppression and dominance of the Other. Therefore, the play Vinegar Tom should not be perceived exclusively as feminist play but as an attempt of understanding and contextualising feminism within much broader social and economic framework which is best comprehended from the perspective of Marxist cultural theory. The way Caryl Churchill intertwines these two theories acknowledges common Marxist thesis that knowing history is a key element of every art vision aspiring to critical reassessment of a society.

\footnotetext{
${ }^{5}$ Such as genocides in Latin America, Iraq, Libya, Syria, or the demonization of "rogue" rulers including Muammar Gaddafi and Saddam Hussein. As we have already seen on the example of McCarthyism, the European and American "heretics" are also not immunized against similar persecutions. Most recent examples are Julian Assange and Chelsea Manning, both activists and devotees of truth and justice.

${ }^{6}$ The controversial interview is available online https://www.youtube.com/watch?v=omnskeu-puE
} 


\section{WORKS CITED:}

Adiseshiah, Sian. "Utopian space in Caryl Churchill's History Plays: Light Shining in Buckinghamshire and Vinegar Tom". Utopian Studies 16.1 (2005): 3-26, Society for Utopian Studies.

Adiseshiah, Sian. Churchill's Socialism: Political Resistance in the Plays of Caryl Churchill. Cambridge Scholars Publishing, 2009.

Aston, Elaine. Caryl Churchil. Plymouth: Northcote House Publishers, 1997.

Aston, Elaine and Ellen Diamond. The Cambridge Companion to Caryl Churchill. Cambridge University Press, 2009.

Brecht, Bertolt. The good person of Szechwan, digitalized by RevSocialist for SocialistStory, 1942. Available online: http://www.socialiststories.com/liberate/The\%20Good\%20Person \%20of\%20Szechuan.pdf

Chodorow, Nancy. "Mothering, male dominance, and capitalism". In Zillah Eisenstein (ed.) Capitalist Patriarchy and the Case of Social Feminism. Monthly Review Press, London, New York, 1979.

Churchill, Caryl. Plays One: Owners, Traps, Vinegar Tom, Light Shining in Buckinghamshire, Cloud Nine. Introduced by the author. Methuen, 1985.

Cousin, Geraldine. Churchill: The Playwright. Methuen, 1989.

Ehreinreich, Barbara and Deirdre English. Witches, Midwives and Nurses. New York: The Feminist Press, 1973.

Eisler, Riane. The Chalice and the Blade. New York: Harper One, 1987.

Figes, Eva. Patriarchal Attitudes: Women in Society. New York: Persea Books, 1986.

Fitzsimmons, Linda. File on Churchill. Methuen Drama, 1989.

Mackay, Christopher S. The Hammer of Witches. A complete translation of The Malleus Maleficarum. Cambridge University Press, 2009.

Petrović, Lena. “Utopijski momenti u dramama M. Držića i M. Ravenhila". Interkulturni horizonti: južnoslovenske/evropske paradigme i srpska književnost. Kragujevac: Filum, 2009.

Roberts, Phillip. About Churchill: The Playwright \& the Work. London: Faber, 2009.

Sullivan, Victoria. "Caryl Churchill”. British Writers. Supplement IV. George Stade and Carol Howard (eds). New York: Charles Scribner's sons, 1997. 


\section{VINEGAR TOM: DRAMA O VJEŠTICAMA U KOJOJ NEMA NIJEDNE VJEŠTICE}

lako se fokusira na lov na vještice iz 17. og vijeka, komad Vinegar Tom zapravo predstavlja dramski prikaz istorijske degradacije žena koja u srednjem vijeku kulminira do njihove potpune demonizacije. Stavljajući pod znak pitanja zvaničnu verziju priče o „vješticama“, Keril Čerčil otkriva istinu o njima kao o „starim, siromašnim, neudatim i seksualno nekonvencionalnim“ ženama (Čerčil 1985). Prateći trag autorke, naša namjera bila je da otkrijemo i dalje objasnimo kako su ženska seksualnost, transgresivna imaginacija i vidarske vještine postale prijetnja za Crkvu i njenu dogmu i kako ova trostruka prijetnja zapravo obuhvata tri najuobičajnije optužbe protiv vještica. Isto tako, u radu ćemo koristeći metode Novog istoricizma pokušati da dovedemo u vezu ovaj jezivi napad i uspon kapitalizma i protestantizma, dvije represivne ideologije koje ne samo da su poslužile kao argument za legitimizovanje ove ženomrzačke kampanje, već se ujedno pojavljuju i kao glavni zagovornici i organizatori čitave ideje i to uz podršku same države. Ono što ovu dramu čini posebno značajnom jeste njena savremenost koja se očituje, između ostalog, u direktnom obraćanju publici i upotrebi moderne odjeće. Stoga, naš zaključak bi bio da svaki istorijski period ima svoje "vještice", bilo da se radi o čitavim nacijama, grupama ljudi ili pojedinačnim disidentima.

Ključne riječi: vještice, žene, lov na vještice, patrijarhat, seksualnost, žrtve. 